\title{
Predicted and observed mortality from vector-borne disease in wildlife: West Nile virus and small songbirds
}

\author{
A. Marm Kilpatrick ${ }^{\mathrm{a}, \mathrm{c}, *}$, Ryan J. Peters $^{\mathrm{a}, \mathrm{b}}$, Alan P. Dupuis II ${ }^{\mathrm{b}}$, Matthew J. Jones ${ }^{\mathrm{b}}$, Peter Daszak ${ }^{\mathrm{c}}$, \\ Peter P. Marra ${ }^{\mathrm{d}}$, Laura D. Kramer ${ }^{\mathrm{b}}$ \\ ${ }^{a}$ University of California, Ecology and Evolutionary Biology, Santa Cruz, CA 95060, USA \\ ${ }^{\mathrm{b}}$ Wadsworth Center, New York State Department of Health, Slingerlands, NY 12159, USA \\ ${ }^{\mathrm{c}}$ Ecohealth Alliance, New York, NY 10001, USA \\ d Migratory Bird Center, Smithsonian Conservation Biology Institute, National Zoological Park, Washington, DC 20008, USA
}

\section{A R T I C L E I N F O}

\section{Article history:}

Received 29 April 2013

Accepted 20 May 2013

Available online 29 June 2013

\section{Keywords:}

Disease

Population

Birds

Epidemiology

West Nile virus

Conservation

\begin{abstract}
A B S T R A C T
Numerous diseases of wildlife have recently emerged due to trade and travel. However, the impact of disease on wild animal populations has been notoriously difficult to detect and demonstrate, due to problems of attribution and the rapid disappearance of bodies after death. Determining the magnitude of avian mortality from West Nile virus (WNV) is emblematic of these challenges. Although correlational analyses have shown population declines coincident with the arrival of the virus, strong inference of WNV as a cause of mortality or a population decline requires additional evidence. We show how integrating field data on mosquito feeding patterns, avian abundance, and seroprevalence can be used to predict relative mortality from vector-borne pathogens. We illustrate the method with a case study on WNV in three species of small songbirds, tufted titmouse (Baeolophus bicolor), Carolina wrens (Thryothorus ludovicianus), and northern cardinals (Cardinalis cardinalis). We then determined mortality, infectiousness, and behavioral response of wrens and titmouse following infection with WNV in laboratory experiments and compared them to a previous study on WNV mortality in cardinals. In agreement with predictions, we found titmouse had the highest mortality from WNV infection, with $100 \%$ of 11 birds perishing within 7 days after infection. Mortality in wrens was significantly lower at 27\% (3/11), but still substantial. Viremia profiles indicated that both species were highly infectious for WNV and could play roles in WNV amplification. These findings suggest that WNV may be killing many small-bodied birds, despite the absence of large numbers of dead birds being observed and testing positive for WNV. More broadly, they illustrate the utility of a framework for predicting relative mortality in hosts from vector-borne disease.
\end{abstract}

(c) 2013 Elsevier Ltd. All rights reserved.

\section{Introduction}

The impact of disease on wild animal populations has been notoriously difficult to detect and demonstrate, due to problems of attribution and the rapid disappearance of bodies after death (McCallum, 2005; McCallum and Dobson, 1995). The clearest examples of disease-caused impacts on wildlife populations come from epidemics in large abundant animals such as anthrax and Rinderpest in African mammals (Holdo et al., 2009), experimental or purposeful viral introductions such as myxomatosis and Australian rabbits (Ratcliffe et al., 1952), and experimental studies that remove pathogens from hosts through treatment (Hudson et al., 1998). For many other diseases and populations, impacts are inferred from long term monitoring and observations of sudden

* Corresponding author at: University of California, Santa Cruz, Dept. Ecology and Evolutionary Biology, EE Biology/EMS, UCSC, Santa Cruz, CA 95060, USA. Tel.: +1 (831) 459-5070.

E-mail address: akilpatr@ucsc.edu (A.M. Kilpatrick). declines, and in rare cases scientists have been able to observe a wave of mortality as a pathogen arrives (Hochachka and Dhondt, 2000; Kilpatrick et al., 2010; Langwig et al., 2012; Lips et al., 2006; Vredenburg et al., 2010). However, in many cases mortality due to disease is difficult to detect and even striking patterns, such as distributional limits coincident with disease boundaries, required experimental infection studies to confirm impacts of disease (e.g., avian malaria and Hawaiian birds; (Van Riper et al., 1986; Warner, 1968)).

A recent introduction of a pathogen to North America, West Nile virus (WNV; Flaviviridae; Flavivirus) in 1999, was also accompanied by waves of mortality in wild birds, with large numbers of dead American crows and Blue jays testing positive for WNV in the northeast USA (Bernard et al., 2001; Nemeth et al., 2007). A decade later, transmission still occurs annually in many bird communities throughout North and South America (Kilpatrick, 2011). Several retrospective analyses have shown population declines in birds coincident with the arrival of WNV as it spread south and west 
from New York, with impacts being largest on corvids (Hochachka et al., 2004; LaDeau et al., 2007; Wheeler et al., 2009). Evidence of WNV-caused mortality in corvids was also provided by experimental infection in laboratory studies (Komar et al., 2003; Reisen et al., 2005). However, evidence of WNV mortality in smaller passerines has been far sparser, with relatively few WNV-infected dead birds collected. The extent to which this is due to poor detectability (Ward et al., 2006) or lack of mortality is not clear.

Two families of small passerines that past studies have suggested may suffer population level impacts from WNV are Paridae (chickadees and titmouse) and Troglodytidae (wrens). Multiple studies have observed declines in one or more species in the family Paridae and Troglodytidae coincident with the arrival of WNV (Bonter and Hochachka, 2003; LaDeau et al., 2007), and several other studies have demonstrated feeding on parids and wrens by WNV mosquito vectors (Hamer et al., 2009; Hassan et al., 2003; Kilpatrick et al., 2006a). However, these data are only suggestive and supportive evidence in the form of WNV-infected dead chickadees, titmouse or wrens is mostly lacking.

The gold standard to determine whether a species suffers mortality from a pathogen, part of Koch's postulates (Koch, 1893), is through experimental infection. There are far too many species of birds in North America to do this for all taxa, and these studies cannot determine whether in fact birds are exposed to a pathogen in nature. For effective conservation planning, there is clearly a need for a framework to determine whether WNV and other vectorborne diseases cause mortality in small avian hosts, and other small wildlife species that are difficult to detect.

Here we describe how one can use field data on the transmission ecology of a vector-borne disease - specifically the feeding patterns of WNV mosquito vectors, avian abundance, and the WNV antibody prevalence of wild-caught birds - to generate hypotheses about differences in mortality from WNV infection between hosts. We illustrate this method with a study on three species of small songbirds, tufted titmouse (Baeolophus bicolor), Carolina wrens (Thryothorus ludovicianus), and northern cardinals (Cardinalis cardinalis). We generated and tested hypotheses about the relative mortality of three species and measured morbidity and mortality following experimental infection with WNV. Our experimental infection studies also provide data on infectiousness for WNV that can be integrated with the aforementioned data on mosquito preferences to determine the role of species in WNV transmission (Hamer et al., 2009; Kilpatrick, 2011; Kilpatrick et al., 2006a).

\section{Methods}

\subsection{Framework for predicting relative host mortality from a vector- borne pathogen}

This framework generates a prediction about the relative mortality from infection with a vector-borne pathogen between two or more species and can be applied to any vector-borne pathogen and host taxa with the data described.

The seroprevalence, $S$, or fraction of a population with antibodies against a pathogen at a point in time is equal to the fraction of the population exposed, $e$, multiplied by the probability of survival $(1-m$, where $m$ is the probability of mortality given infection), divided by the fraction of the original population size after exposure, $(e(1-m)+1-\mathrm{e})$ :

$S=e(1-m) /(1-e m)$

The fraction of the population exposed, $e$, will increase asymptotically with the average number of infective bites, $I$, each host receives (Smith et al., 2005):

$e=1-(1+I / k)^{-k}$ where $k$ is parameter describing the degree to which mosquitoes feed more on some individuals of a species than others (Dye and Hasibeder, 1986). Previous work suggests that in some populations $k$ is approximately 0.25 (Smith et al., 2005). Simulations suggest that using $k=0.25$ produces qualitatively correct predictions about which species suffers higher mortality as long as $k$ is not too small (i.e. $<0.1$, as long as bites are not extremely concentrated on just a few individuals).

The number of bites that a subset of the population is exposed to will increase with the host utilization index (sometimes termed mosquito preference, forage ratio, or host selection index) of vectors, $U$, on that subpopulation, where the utilization index is the fraction of bloodmeals, $b$, from that subpopulation divided by the relative abundance of that subpopulation, a (e.g. the fraction of all hosts made up by a species):

$U=b / a$

Thus, if data on host utilization, $U$, and seroprevalence, $S$, is available for two or more species at the same site(s), they can be used to predict which species has a higher mortality probability, $m$, given infection. First, it is necessary to invert Eq. (2) and derive an approximate value of infective bites, $I$, using the measured seroprevalence, $S$ :

$I \cong k\left[(1 /(1-S))^{1 / k}-1\right]$

where a value of $k=0.25$ is often valid. We then computed the ratio(s) and confidence bounds of predicted mortality for each of the two or more species $(i=1,2, \ldots)$ :

$m_{1} / m_{2} \propto\left(U_{1} / U_{2}\right) /\left(I_{1} / I_{2}\right)$

A ratio greater than one indicates that species 1 suffers higher mortality once infected than species 2 . It is worth noting that the ratio derived cannot be used to estimate the exact mortality in a species due to the approximations made in Eq. (4), but it does indicate the relative difference in mortality (i.e., a larger ratio indicates a larger difference in mortality, all else being equal).

\subsection{Sites}

We determined mosquito feeding patterns, avian abundance, and WNV antibody prevalence in $\sim 1 \mathrm{~km}$ diameter areas at three urban sites (Foggy Bottom, DC, Baltimore, MD, and the National Mall, DC), two residential sites (Takoma Park, MD and Bethesda, MD) and two park sites surrounded by residential development (Rock Creek Park Meadowside Nature Center in Rockville, MD, and Fort Dupont Park in southeast DC) (Kilpatrick et al., 2006a,b) from 2004 to 2008. Evidence of WNV transmission (infected mosquitoes or antibody-positive resident (non-migratory) hatch-year birds) was present at all sites except Rock Creek Park in 2005 (Kilpatrick et al., unpub. data).

\subsection{Mosquito feeding patterns}

We trapped mosquitoes at each site with at least eight CDC light traps, four CDC gravid traps and by aspirating the surfaces of vegetation with a large backpack mounted aspirator. Sites were trapped for two nights approximately every 2-3 weeks between May and mid-October each year. Mosquitoes were identified to species and all partially or fully engorged mosquitoes were stored in a freezer at $-80^{\circ} \mathrm{C}$ for subsequent host identification. We used PCR to molecularly identify engorged Culex mosquitoes to distinguish between $C x$. pipiens, $C x$. restuans, and $C x$. salinarius (Crabtree et al., 1995). We only used data from $C x$. pipiens or $C x$. restuans to estimate feeding utilizations, because these two species have similar feeding patterns, whereas $C x$. salinarius feeds on a very 
different set of hosts (Apperson et al., 2002, 2004). We identified the vertebrate source of each blood meal by PCR amplification of the cytochrome $b$ gene and nucleotide sequencing of the amplified product (Kilpatrick et al., 2006a). We compared the sequence to known sequences in Genbank using the blastn search tool. As described above, we calculated a mosquito utilization index for titmouse and wrens by dividing the fraction of bloodmeals at each site identified as titmouse or wren by the relative abundance (i.e. fraction of the avian community) of the same species. Abundances were estimated from 4 to 6 six minute unlimited distance point counts conducted at dawn monthly from May to September and analyzed with program Distance (Thomas et al., 2004). A mosquito utilization index, $U$, of one indicates that a species is fed on in proportion to their abundance, a value less than one indicates underutilization, and a value greater than one indicates overutilization. In addition to data for wrens and titmouse, we show values of the mosquito utilization index, $U$, (and seroprevalence, $S$ ) for northern cardinal, a common species of bird that shows high WNV seroprevalence, and suffered moderate (22\%; 2/9 birds) mortality in the laboratory following experimental infection with WNV (Komar et al., 2005).

\subsection{Avian serology}

We captured birds in 20 to 40 6-18 m long mist nets operated from dawn until early afternoon for 2-3 days at each site approximately monthly from mid-July to early October. Birds were extracted and taken to a banding station where they were aged, sexed, banded with an aluminum USFWS band, weighed, and a $0.1 \mathrm{ml}$ blood sample was taken by brachial venipuncture. Blood was tested for flavivirus antibodies using an enzyme-linked immunosorbent assay (ELISA; (Ebel et al., 2002)). We confirmed a random sample of $18 \%$ of flavivirus antibody-positive samples (185 of 1026) by a plaque reduction neutralization test (Calisher et al., 1989; Ebel et al., 2002; Wong et al., 2004). None of these samples indicated exposure to St. Louis Encephalitis virus, so we interpreted all flavivirus positive samples as indicating prior exposure to WNV and survival in estimating WNV seroprevalence, $S$.

\subsection{Experimental infection}

We captured 11 hatch-year Carolina wrens and 12 tufted titmouse (six hatch-year and six after-hatch year birds) from Montgomery and Anne Arundel Counties in Maryland during the last week of August, 2009. Birds were transported from the National Zoo to the New York State Department of Health where they were held for 2 weeks for acclimation. On the 15 th day, a $0.05 \mathrm{ml}$ blood sample was taken by brachial venipuncture to determine whether any birds had flavivirus antibodies by ELISA. All birds tested negative.

Birds in captivity were given water ad libitum, and fed mealworms, waxworms, and a vitamin supplemented "meat mash" consisting of beef, wheat germ, whole grain cereal, boiled egg, carrot, bonemeal, and powdered milk. Titmouse were also fed sunflower seeds.

We initially separated the birds into treatment (infection: nine wrens, eight titmouse) and control (mock infection: two wrens and four titmouse) groups. Treatment birds were infected by subcutaneous injection in the cervical region with $10^{4} \mathrm{PFU}$ of WNV (strain 03-1956 in the WN02 clade (Davis et al., 2005)) in animal diluent, PBS w/1\% fetal bovine serum. All birds were bled every other day with half the birds bled on day 1 post-infection (PI) and the other half on day 2 so that half the birds were sampled on each day PI, 16. All control birds survived until 2 weeks after mock infection, and by which time all birds infected in this experiment had recovered or perished.

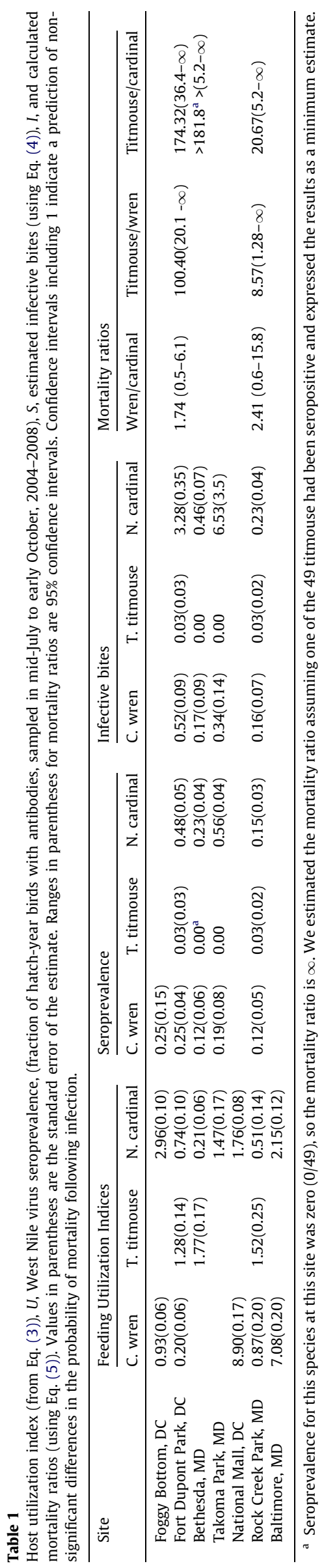


Normally all surviving (control and treatment) birds would have been sacrificed on day 14 post-infection. However, in order to maximize sample sizes for survival and viremia profiles, we held the control birds for 14 additional days after the initial infection study was completed (28 days after the start of the first experiment). We then infected these previous "control" birds and bled these birds as described above and measured survival and viremia. Since they served as their own controls in terms of examining the effect of bleeding and handling during the first experiment, we treated all birds similarly in analyses of WNV viremia and mortality from WNV infection described below. Fourteen days after the second infection, all remaining birds were bled for evidence of WNV antibodies and were euthanized by an overdose of pentobarbitol.

WNV viremia was measured by plaque assay on Vero cells (Payne et al., 2006) with a limit of detection of $10^{1.7} \mathrm{PFU} / \mathrm{ml}$, and average daily viremias were calculated after log-transformation. We calculated the host competence for each species by estimating the average infectiousness of each bird on days 1-6 PI using a viremia-infectiousness relationship for $C x$. pipiens (\% of mosquitoes infectious (transmitting) $=0.1349 \times \log _{10}$ (viremia) -0.6235 ; (Kilpatrick et al., 2007)), and multiplied this average by the number of days birds were viremic. Kaplan-Meier survival curves of the two species following infection were compared with a log-rank test on right-censored data using the date of sacrifice for birds surviving infection as the censor date.

We examined the persistence of live virus in bird tissues by harvesting approximately $0.2 \mathrm{~g}$ portions of brain, heart, kidney, spleen, lung, and skin (inoculation site) from all birds surviving infection (eight wrens and zero titmice). Tissues were homogenized in BA1 diluent and were co-cultured as previously described (Tesh et al., 2005). Briefly, samples were homogenized in $2 \times$ antibiot- ics/fungicide and then $0.1 \mathrm{ml}$ of the homogenate was inoculated in duplicate on Vero cell monolayers. Cultures were observed for 7 days for cytopathic effect (CPE). If CPE was not present, then cultures were passed to fresh monolayers. Samples were considered negative for persistent infectious virus if after three successive passages CPE was not evident. If CPE was observed, then cultures were confirmed by RT-PCR. Infectious viral loads were not calculated since the assay used (co-culture) is not quantitative.

To determine whether birds showing illness or clinical signs would be evident in the field and to what extent infected birds might be at greater susceptibility to predation we observed the behavior of birds using instantaneous sampling (Altmann, 1974) with five $10 \mathrm{~s}$ sampling periods each day for each bird spaced over a $30 \mathrm{~min}$ period in the afternoon (1200-1600). We ranked the behaviors on a nine point scale from dead to highly active (Table S1).

\section{Results}

Tufted titmouse were present at four of seven sites where they made up $2.8 \%$ ( \pm 1 SE $2.9 \%$ ) of the avian community, and we identified Culex pipens or $C x$. restuans bloodmeals from them at three sites (Table 1). Carolina wrens were present at all seven sites where they made up $2.7 \%( \pm 1 \%)$ of the avian community and we identified bloodmeals from wrens at 5 of 7 sites. Carolina wrens were fed on by mosquitoes significantly more than expected given their availability at two sites, less than expected at one site and fed on in proportion to their abundance at two sites, whereas Culex mosquitoes fed on titmouse slightly more frequently than expected than their abundance at all three sites (Table 1). Northern cardinals were present at all seven sites, made up $8.5 \%( \pm 5.2 \%)$ of the avian
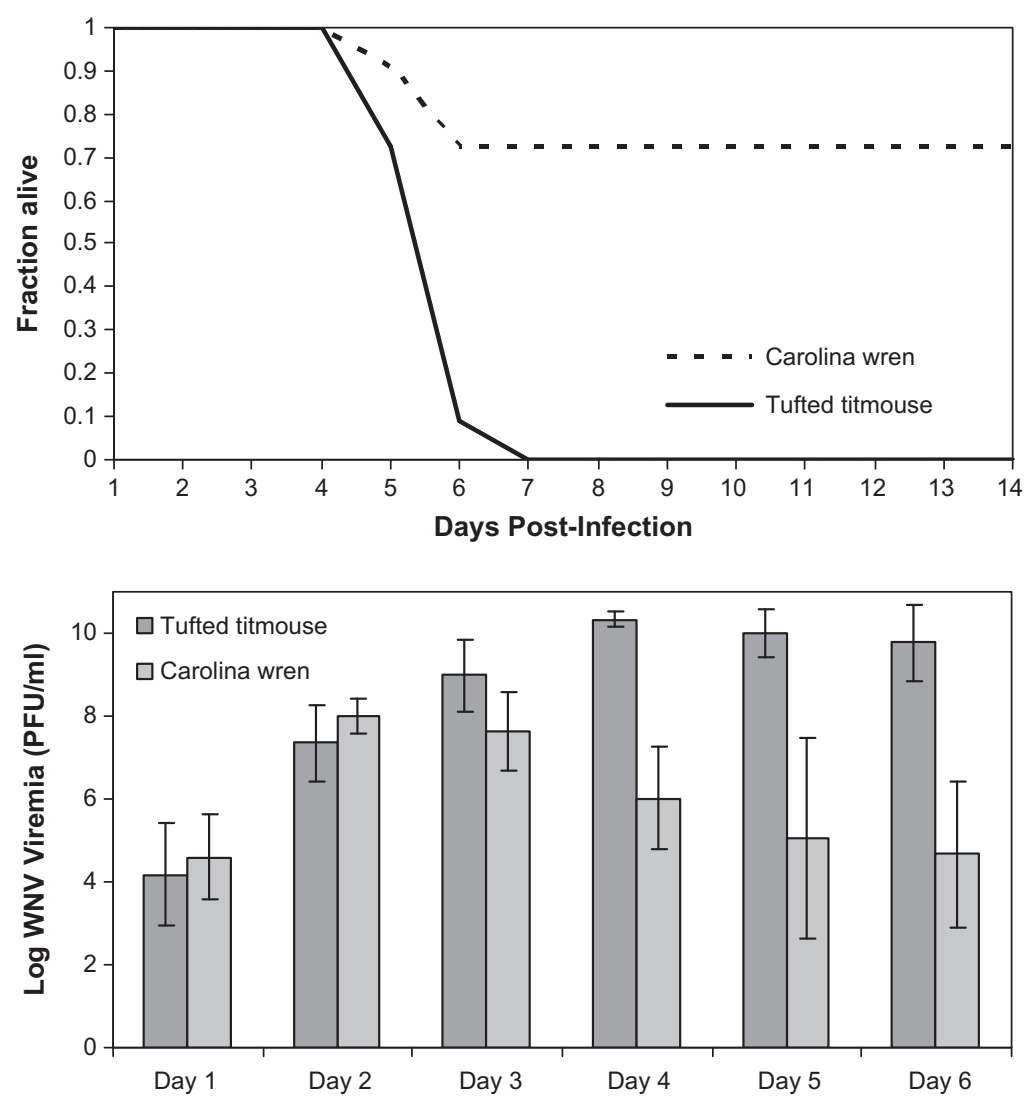

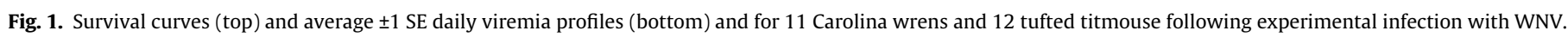


community, and were fed on at all seven sites. Feeding on cardinals varied from being half to twice as frequently as expected based on their abundance (Table 1). The antibody prevalence of hatch-year birds caught in mid-July to early October was $17.5 \%$ for wrens and $34.8 \%$ cardinals, whereas only 3 of the 176 titmouse $(1.7 \%)$ tested positive for WNV antibodies (Table 1). We used these estimates of seroprevalence, $S$, to estimate the number of infectious bites, $I$, (Eq. (4)) and combined these with mosquito utilization values to generate multiple mortality ratios or predictions (Eq. (5)) about the relative mortality of wrens, cardinals and titmouse (Table 1 ; rightmost three columns): mortality was predicted to be lowest in cardinals ( $22 \%$ or $2 / 9$ birds died in a previous experimental infection; (Komar et al., 2005)), slightly (but not significantly; confidence intervals for mortality ratios included 1) higher in wrens, and significantly higher in titmouse.

We then performed an experimental infection study in the laboratory. All control birds survived the handling and bleeding regiment during the first experiment. Over the course of the two experiments (see Section 2) we experimentally infected 11 wrens and 12 titmouse with WNV (Fig. 1a). Three of the 11 (27\%) wrens died following WNV infection on days 7, 7, and 8 post-infection (PI) and all 12 of the tufted titmouse died following infection (Fig. 2; three birds on day five, seven birds on day six, one bird on day seven, and one an additional bird on day two whose death may have been related to handling). Survival was significantly higher in wrens than titmouse (log-rank test: $\chi=19.8 ; \mathrm{d} f=1$, $p<0.001)$. It is worth noting that although none of the control birds died from the bleeding regiment, it is still possible that the mortality of birds infected with WNV could have been slightly inflated by being bled every other day.
The behavior of wren and titmouse following infection also differed significantly (Fig. 2). Titmouse showed a highly significant decline in behavioral score becoming less active and alert with increasing days since infection (mixed effects model using the lme4 package in $\mathrm{R}$ (v2.15) with species interacting with days since infection interaction as fixed effects and bird as a random effect: species effect: titmouse coefficient $-0.29 \pm \mathrm{SE}=0.39, t=-0.735$, $p>0.5$; titmouse-by-days since infection coeff. $-0.43 \pm 0.10$, $t=-4.460, p<0.001)$. The behavior of the wrens who succumbed to infection were not significantly different from those that survived (mixed effects model with days since infection interacting with succumbed to WNV infection as fixed effects and bird as a random effect: days since infection-by-succumbed coeff. $0.13 \pm 0.14, t=0.95, p>0.3$ ). Only two of the three wrens that died showed behaviors associated with sickness and these behaviors were only observed the day before death.

The average WNV viremia (concentration of virus in the blood) of wrens was significantly lower than titmouse, and peaked on day 2 at $10^{7.8} \mathrm{PFU} / \mathrm{ml}$, whereas titmouse viremia peaked on day 4 and remained high through day 6 (Fig. 1b; mixed effects model with bird as random effect: titmouse species coefficient $2.58 \pm 0.49$; $p<0.001$ ). The reservoir competence index (Komar et al., 2003) of titmouse (3.15 or an average infectiousness of $52.4 \%$ across 6 days) was higher than that recorded for any of the other $50+$ species that have been studied (Kilpatrick et al., 2007), partly due to a 6 day long viremic period (other highly infectious species like crows and jays died mostly on days 4 and $5 \mathrm{PI}$; (Komar et al., 2003; Reisen et al., 2005)).

As in previous studies (Nemeth et al., 2009; Reisen et al., 2006; Wheeler et al., 2012), infectious virus or viral RNA was detected
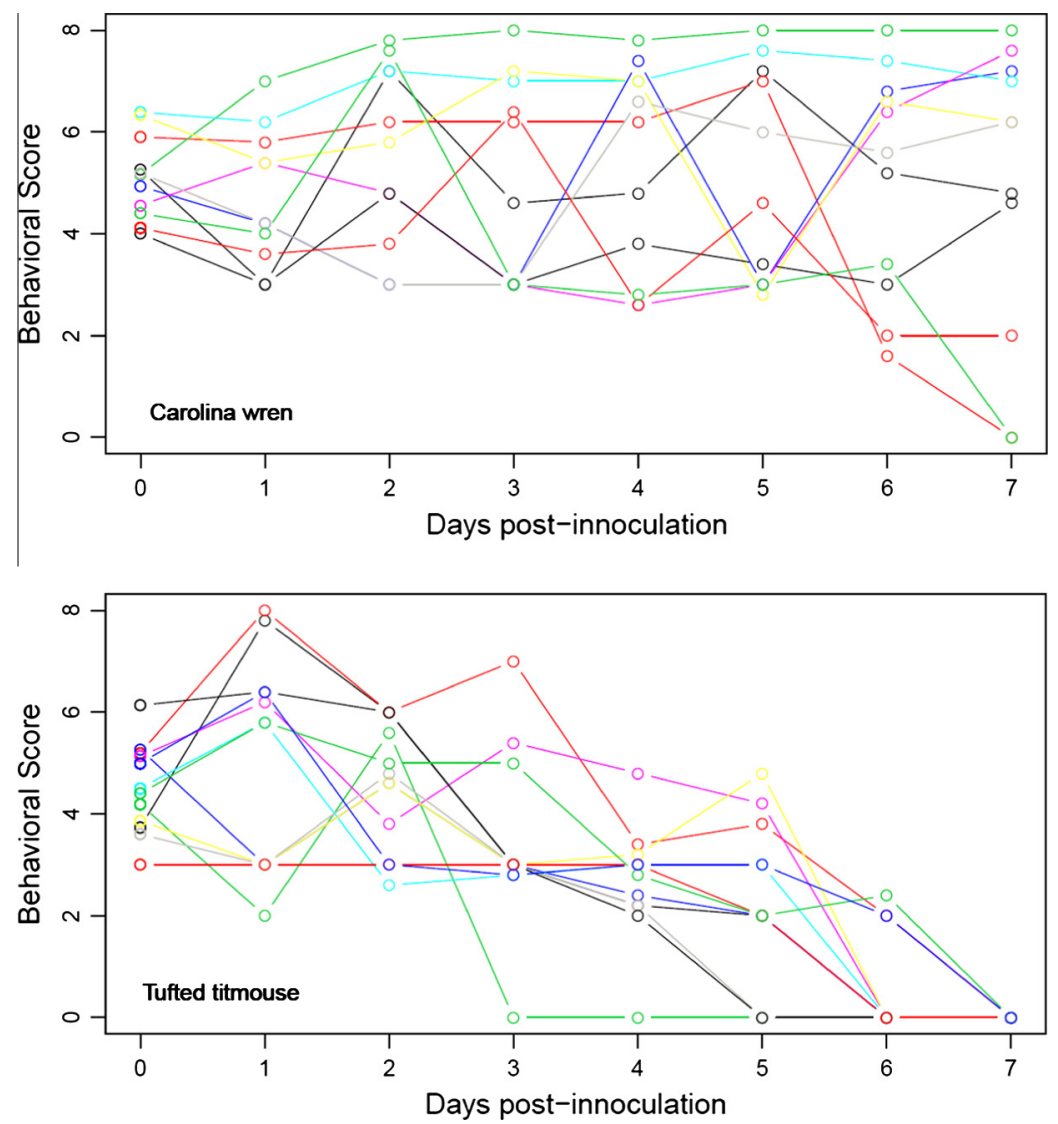

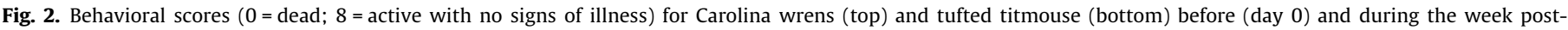
innoculation. Each color indicates a different individual bird. Note that analyses only use the non-zero values. See Table S1 for explanation of all behavioral codes. 
several weeks post-infection. We isolated virus from at least one tissue from all wrens surviving infection at 29 days post-infection (and viral RNA even more frequently), with the kidneys and spleens being frequently infected (Tables S2 and S3).

\section{Discussion}

Analysis of population trends following the arrival of WNV suggested that tufted titmouse, chickadees, and house wrens were significantly impacted by disease, with the largest drop in midAtlantic populations following the intense 2003 WNV epidemic (LaDeau et al., 2007). However, the inference from that study and others (Bonter and Hochachka, 2003; Wheeler et al., 2009) that trends in these species, as well as several other small songbirds, were due to WNV was indirect. Similarly, although songbirds have tested positive for WNV in some dead bird surveillance efforts for WNV (Bernard et al., 2001; Nemeth et al., 2007), the relative numbers are often small and thus give little hard evidence for WNV impact. Here we used a model framework to generate the hypothesis that titmouse and wrens are perishing in the field from WNV infection with equal or higher probability than a previously studied species, Northern cardinals. We found strong support for this hypothesis in a rigorous laboratory infection experiment in that titmouse were highly susceptible to mortality from WNV infection, with all birds perishing within 7 days after infection. Nearly $30 \%$ of wrens, which were predicted to suffer lower, but significant mortality, also died following infection. These results which agree well with predictions based on serology and feeding preferences (Table 1) highlight the utility of our framework to predict the relative WNV mortality of different species in the absence of experimental infection studies. With the growing number of studies that estimate mosquito utilization index values (Hamer et al., 2009; Hassan et al., 2003; Kent et al., 2009; Kilpatrick et al., 2006a; Thiemann et al., 2011), and dozens of studies on WNV seroprevalence it is now possible to make predictions about relative susceptibility to mortality from WNV for many species of birds that have not been studied but may be dying from this disease.

These results on wren and titmouse mortality suggest that WNV may be killing many smaller-bodied birds that are not found in large numbers in WNV dead bird collections. Our behavioral studies suggest that infected titmouse may exhibit sick behavior before death and this might be apparent through citizen science projects like Feederwatch (Hochachka and Dhondt, 2000), whereas other species like Carolina wrens show relatively little change in behavior over most of the viremic period, even if they eventually die from the disease. Actions to reduce WNV impacts on these and other species include reducing WNV transmission by reducing mosquito larval habitat of WNV vectors (e.g., Culex pipiens, $C x$. restuans, $C x$. tarsalis; (Kilpatrick et al., 2005)) by removing man-made containers such as tires, clogged gutters, etc. Disease reduction through habitat modification to reduce vector density should be considered an important part of habitat restoration for birds susceptible to WNV and other mosquito-borne pathogens.

Our results also provide valuable information about the host competence of these two species (and other species in the previously unstudied families Paridae and Troglodytidae, because competence is phylogenetically conserved to some extent; (Kilpatrick et al., 2006a)). These data on host infectiousness have proven to be an integral part of determining the contribution of hosts to transmission (Kilpatrick, 2011) as well as predicting spatial and temporal patterns of WNV transmission (Hamer et al., 2011; Kilpatrick et al., 2006a). We found that both wrens and titmouse were highly infectious for WNV mosquito vectors, and are fed on by these mosquitoes (Fig. 1; (Hamer et al., 2008)). However, due to their low relative abundance and only moderate feeding utiliza- tions, they are likely to play only minor roles in WNV amplification compared to species such as American robins (Hamer et al., 2009; Kent et al., 2009; Kilpatrick, 2011; Kilpatrick et al., 2006a).

Our host competence data also informs our broader understanding of host-parasite relationships. For example, the top 15 most infectious hosts for WNV (Kilpatrick et al., 2007) now span 12 families (including four non-passerine families), which demonstrates the ability of WNV to efficiently replicate in a broad range of hosts, and challenges assertions that only passerines or corvids are highly competent for WNV.

More broadly, our findings demonstrate the value of both field and experimental evidence for understanding disease susceptibility in species conservation. As more pathogens are spread among continents and infect new hosts, there is an urgent need to predict and mitigate the impacts of emerging diseases on wildlife populations (Kilpatrick and Randolph, 2012).

\section{Acknowledgements}

We thank Will Janousek for assistance capturing and transporting birds, the Smithsonian's Neighborhood Nestwatch program and residents, the staff of Rock Creek Park (Meadowside Nature Center), Fort Dupont Park, the Smithsonian National Museum of Natural History, the National Gallery of Art and the Hirshhorn museum for permission to use their property. We are indebted to Montgomery County Parks and the Patuxent National Wildlife Refuge for permission to use birds from these lands for this study. Funding was provided by NSF Grant EF-0914866, NIH Grant 1R01AI090159-01, and NIAID Contract \#NO1-AI-25490. Birds were collected under USFWS permit MB177891-1. Experimental infection studies were approved by the Wadsworth Center, New York State Department of Health, animal use protocol 09-412.

\section{Appendix A. Supplementary material}

Supplementary data associated with this article can be found, in the online version, at http://dx.doi.org/10.1016/j.biocon.2013. 05.015 .

\section{References}

Altmann, J., 1974. Observation study of behavior - sampling methods. Behaviour 49, 227-267.

Apperson, C.S., Harrison, B.A., Unnasch, T.R., Hassan, H.K., Irby, W.S., Savage, H.M. Aspen, S.E., Watson, D.W., Rueda, L.M., Engber, B.R., Nasci, R.S., 2002. Hostfeeding habits of Culex and other mosquitoes (Diptera: Culicidae) in the Borough of Queens in New York city, with characters and techniques for identification of Culex mosquitoes. J. Med. Entomol. 39, 777-785.

Apperson, C.S., Hassan, H.K., Harrison, B.A., Savage, H.M., Aspen, S.E., Farajollahi, A. Crans, W., Daniels, T.J., Falco, R.C., Benedict, M., Anderson, M., McMillen, L. Unnasch, T.R., 2004. Host feeding patterns of established and potential mosquito vectors of West Nile virus in the eastern United States. VectorBorne Zoo. Dis, 4, 71-82.

Bernard, K.A., Maffei, J.G., Jones, S.A., Kauffman, E.B., Ebel, G.D., Dupuis, A.P., Ngo K.A., Nicholas, D.C., Young, D.M., Shi, P.Y., Kulasekera, V.L., Eidson, M., White D.J., Stone, W.B., Kramer, L.D., 2001. West Nile virus infection in birds and mosquitoes, New York state, 2000. Emerg. Infect. Dis. 7, 679-685.

Bonter, D., Hochachka, W.M., 2003. Declines of chickadees and corvids: possible impacts of West Nile virus. Am. Birds: 103rd Christmas Bird Count, 22-25.

Calisher, C.H., Karabatsos, N., Dalrymple, J.M., Shope, R.E., Porterfield, J.S Westaway, E.G., Brandt, W.E., 1989. Antigenic relationships between flaviviruses as determined by cross-neutralization tests with polyclonal antisera. J. Gen. Virol. 70, 37-43.

Crabtree, M.B., Savage, H.M., Miller, B.R., 1995. Development of a species-diagnostic polymerase chain reaction assay for the identification of Culex vectors of St Louis encephalitis virus based on interspecies sequence variation in ribosomal DNA spacers. Am. J. Trop. Med. Hyg. 53, 105-109.

Davis, C.T., Ebel, G.D., Lanciotti, R.S., Brault, A.C., Guzman, H., Siirin, M., Lambert, A., Parsons, R.E., Beasley, D.W.C., Novak, R.J., Elizondo-Quiroga, D., Green, E.N., Young, D.S., Stark, L.M., Drebot, M.A., Artsob, H., Tesh, R.B., Kramer, L.D., Barrett A.D.T., 2005. Phylogenetic analysis of North American West Nile virus isolates, 2001-2004: Evidence for the emergence of a dominant genotype. Virology 342, $252-265$. 
Dye, C., Hasibeder, G., 1986. Population dynamics of mosquito-borne disease effects of flies which bite some people more frequently than others. Trans. Roy. Soc. Trop. Med. Hyg. 80, 69-77.

Ebel, G.D., Dupuis Alan II, P., Nicholas, D., Young, D., Maffei, J., Kramer, L.D., 2002. Detection by enzyme-linked immunosorbent assay of antibodies to West Nile virus in birds. Emerg. Infect. Dis. 8, 979-982.

Hamer, G.L., Chaves, L.F., Anderson, T.K., Kitron, U.D., Brawn, J.D., Ruiz, M.O., Loss, S.R., Walker, E.D., Goldberg, T.L., 2011. Fine-scale variation in vector host use and force of infection drive localized patterns of West Nile virus transmission. PLOS ONE 6.

Hamer, G.L., Kitron, U.D., Brawn, J.D., Loss, S.R., Ruiz, M.O., Goldberg, T.L., Walker E.D., 2008. Culex pipiens (Diptera: Culicidae): a bridge vector of West Nile virus to humans. J. Med. Entomol. 45, 125-128.

Hamer, G.L., Kitron, U.D., Goldberg, T.L., Brawn, J.D., Loss, S.R., Ruiz, M.O., Hayes, D.B., Walker, E.D., 2009. Host selection by Culex pipiens mosquitoes and West Nile virus amplification. Am. J. Trop. Med. Hyg. 80, 268-278.

Hassan, H.K., Cupp, E.W., Hill, G.E., Katholi, C.R., Klingler, K., Unnasch, T.R., 2003. Avian host preference by vectors of eastern equine encephalomyelitis virus. Am. J. Trop. Med. Hyg. 69, 641-647.

Hochachka, W.M., Dhondt, A.A., 2000. Density-dependent decline of host abundance resulting from a new infectious disease. Proc. Nat. Acad. Sci. USA 97, 5303-5306.

Hochachka, W.M., Dhondt, A.A., McGowan, K.J., Kramer, L.D., 2004. Impact of West Nile virus on American crows in the northeastern United States, and its relevance to existing monitoring programs. EcoHealth 1, 60-68.

Holdo, R.M. Sinclair, A.R.E, Dobson, A.P. Metzger, K.L., Bolker, B.M., Ritchie, M.E. Holt, R.D., 2009. A disease-mediated trophic cascade in the Serengeti and its implications for ecosystem C. PLoS Biol. 7.

Hudson, P.J., Dobson, A.P., Newborn, D., 1998. Prevention of population cycles by parasite removal. Science 282, 2256-2258.

Kent, R., Juliusson, L., Weissmann, M., Evans, S., Komar, N., 2009. Seasonal blood feeding behavior of Culex tarsalis (Diptera: Culicidae) in Weld county, Colorado, 2007. J. Med. Entomol. 46, 380-390.

Kilpatrick, A.M., 2011. Globalization, land use, and the invasion of West Nile virus. Science 334, 323-327.

Kilpatrick, A.M., Briggs, C.J., Daszak, P., 2010. The ecology and impact of chytridiomycosis, an emerging disease of amphibians. Trends Ecol. Evol. 25, 109-118.

Kilpatrick, A.M., Daszak, P., Jones, M.J., Marra, P.P., Kramer, L.D., 2006a. Host heterogeneity dominates West Nile virus transmission. Proc. Roy. Soc. B - Biol. Sci. 273, 2327-2333.

Kilpatrick, A.M., Kramer, L.D., Campbell, S., Alleyne, E.O., Dobson, A.P., Daszak, P. 2005. West Nile virus risk assessment and the bridge vector paradigm. Emerg. Infect. Dis. 11, 425-429.

Kilpatrick, A.M., Kramer, L.D., Jones, M.J., Marra, P.P., Daszak, P., 2006b. West Nile virus epidemics in North America are driven by shifts in mosquito feeding behavior. PLoS Biol. 4, 606-610.

Kilpatrick, A.M., LaDeau, S.L., Marra, P.P., 2007. Ecology of West Nile virus transmission and its impact on birds in the western hemisphere. Auk 124 1121-1136.

Kilpatrick, A.M., Randolph, S.E., 2012. Drivers, dynamics, and control of emerging vector-borne zoonotic diseases. Lancet 380, 1946-1955.

Koch, R., 1893. Über den augenblicklichen stand der bakteriologischen choleradiagnose. Zeitschrift für Hygiene und Infectionskrankheiten 14, 319333.

Komar, N., Langevin, S., Hinten, S., Nemeth, N., Edwards, E., Hettler, D., Davis, B. Bowen, R., Bunning, M., 2003. Experimental infection of North American birds with the New York 1999 strain of West Nile virus. Emerg. Infect. Dis. 9, 311322.

Komar, N., Panella, N.A., Langevin, S.A., Brault, A.C., Amador, M., Edwards, E., Owens, J., 2005. Avian hosts for West Nile virus in St. Tammany Parrish, Louisiana, 2002. Am. J. Trop. Med. Hyg. 73, 1031-1037.

LaDeau, S.L., Kilpatrick, A.M., Marra, P.P., 2007. West Nile virus emergence and large-scale declines of North American bird populations. Nature 447, 710-713.
Langwig, K.E., Frick, W.F., Bried, J.T., Hicks, A.C., Kunz, T.H., Kilpatrick, A.M., 2012. Sociality, density-dependence and microclimates determine the persistence of populations suffering from a novel fungal disease, white-nose syndrome. Ecol. Lett. 15, 1050-1057.

Lips, K.R., Brem, F., Brenes, R., Reeve, J.D., Alford, R.A., Voyles, J., Carey, C., Livo, L., Pessier, A.P., Collins, J.P., 2006. Emerging infectious disease and the loss of biodiversity in a neotropical amphibian community. Proc. Nat. Acad. Sci. USA $103,3165-3170$

McCallum, H., 2005. Inconclusiveness of chytridiomycosis as the agent in widespread frog declines. Conserv. Biol. 19, 1421-1430.

McCallum, H., Dobson, A., 1995. Detecting disease and parasite threats to endangered species and ecosystems. Trends Ecol. Evol. 10, 190-194.

Nemeth, N., Young, G., Ndaluka, C., Bielefeldt-Ohmann, H., Komar, N., Bowen, R., 2009. Persistent West Nile virus infection in the house sparrow (Passer domesticus). Arch. Virol. 154, 783-789.

Nemeth, N.M., Beckett, S., Edwards, E., Klenk, K., Komar, N., 2007. Avian mortality surveillance for West Nile virus in Colorado. Am. J. Trop. Med. Hyg. 76, 431-437.

Payne, A.F., Binduga-Gajewska, I., Kauffman, E.B., Kramer, L.D., 2006. Quantitation of flaviviruses by fluorescent focus assay. J. Virol. Methods 134, 183-189.

Ratcliffe, F.N., Myers, K., Fennessy, B.V., Calaby, J.H., 1952. Myxomatosis in Australia - a step towards the biological control of the rabbit. Nature 170, 7-11.

Reisen, W.K., Fang, Y., Lothrop, H.D., Martinez, V.M., Wilson, J., O’Connor, P., Carney, R., Cahoon-Young, B., Shafii, M., Brault, A.C., 2006. Overwintering of West Nile virus in southern California. J. Med. Entomol. 43, 344-355.

Reisen, W.K., Fang, Y., Martinez, V.M., 2005. Avian host and mosquito (Diptera: Culicidae) vector competence determine the efficiency of West Nile and St. Louis encephalitis virus transmission. J. Med. Entomol. 42, 367-375.

Smith, D.L., Dushoff, J., Snow, R.W., Hay, S.I., 2005. The entomological inoculation rate and Plasmodium falciparum infection in African children. Nature 438, 492495.

Tesh, R.B., Siirin, M., Guzman, H., da Rosa, A., Wu, X.Y., Duan, T., Lei, H., Nunes, M.R., Xiao, S.Y., 2005. Persistent West Nile virus infection in the golden hamster: studies on its mechanism and possible implications for other flavivirus infections. J. Infect. Dis. 192, 287-295.

Thiemann, T.C., Wheeler, S.S., Barker, C.M., Reisen, W.K., 2011. Mosquito host selection varies seasonally with host availability and mosquito density. PLoS Neglect. Trop. Dis. 5.

Thomas, L., Laake, J.L., Strindberg, S., Marques, F.F.C., Buckland, S.T., Borchers, D.L., Anderson, D.R., Burnham, K.P., Hedley, S.L., Pollard, J.H., Bishop, J.R.B., 2004. Distance 4.1. Release 2. Research Unit for Wildlife Population Assessment. University of St. Andrews, UK.

Van Riper III, C., Van Riper, S.G., Goff, M.L., Laird, M., 1986. The epizootiology and ecological significance of malaria in Hawaiian (USA) land birds. Ecol. Monogr. 56, 327-344.

Vredenburg, V.T., Knapp, R.A., Tunstall, T.S., Briggs, C.J., 2010. Dynamics of an emerging disease drive large-scale amphibian population extinctions. Proc. Nat. Acad. Sci. USA 107, 9689-9694.

Ward, M.R., Stallknecht, D.E., Willis, J., Conroy, M.J., Davidson, W.R., 2006. Wild bird mortality and West Nile virus surveillance: biases associated with detection, reporting, and carcass persistence. J. Wildl. Dis. 42, 92-106.

Warner, R.E. 1968. The role of introduced diseases in the extinction of the endemic Hawaiian avifauna. Condor 70, 101-120.

Wheeler, S.S., Barker, C.M., Fang, Y., Armijos, M.V., Carroll, B.D., Husted, S., Johnson, W.O., Reisen, W.K., 2009. Differential impact of West Nile virus on California birds. Condor 111, 1-20.

Wheeler, S.S., Langevin, S.A., Brault, A.C., Woods, L., Carroll, B.D., Reisen, W.K., 2012. Detection of persistent West Nile virus RNA in experimentally and naturally infected avian hosts. Am. J. Trop. Med. Hyg. 87, 559-564.

Wong, S.J., Demarest, V.L., Boyle, R.H., Wang, T., Ledizet, M., Kar, K., Kramer, L.D., Fikrig, E., Koski, R.A., 2004. Detection of human anti-flavivirus antibodies with a West Nile virus recombinant antigen microsphere immunoassay. J. Clin. Microbiol. 42, 65-72. 